\title{
Proteomic Analysis of Sensitive and Resistant Isolates of Escherichia coli in Understanding Target(s) of a Cyanobacterial Biomolecule Hapalindole-T
}

\author{
Manoj Kumar Tripathi' ${ }^{1}$, Maheep Kumar' ${ }^{1}$, Deepali S ${ }^{1}$, Ravi Kumar Asthana ${ }^{1}$ and Subhasha Nigam ${ }^{2 *}$
}

${ }^{1}$ Centre of Advanced Study in Botany, Banaras Hindu University, Varanasi, India

${ }^{2}$ Amity Institute of Biotechnology, Amity University, Noida, India

\begin{abstract}
A broad spectrum biomolecule Hapalindote-T, from a cyanobacterium Fischerella sp. colonizing Neem tree bark was used for its targets using Escherichia coli. The cellular extracts of Hap-Ts (sensitive) and Hap-TR (resistant) of E. coli were subjected to 2DGE. The protein spots (selected) with altered expression were analysed by LC-MS. The data obtained was matched with database of $E$. coli. Seventeen proteins were found with altered expression level. Three membrane proteins, OmpP, Agn43A and LysU, found in Hap-Ts strain were absent in the Hap-T ${ }^{\mathrm{R}}$ strain However, fourteen proteins, AspA, GlpK, LpdA, HsIU, GInA, SucB, YihT, GalF, MDH, RfbB, RmIB, AcrAB, FabB and GapA, related to certain metabolic pathways of the cell and overproduced in the extract of Hap-TR strain. The seventeen screened proteins were related with vital metabolic pathways including membrane protein (Omp P), in $E$. coli. The results indicated that these proteins might be the cause of resistance in $E$. coli. These results suggested that overproduced proteins/enzymes in the resistant strain might be a survival strategy under Hap-T stress and could be used as signature protein for the development of new drugs.
\end{abstract}

Keywords: Cyanobacterium; Hap-T; Drug target; 2-DGE; E. coli

\section{Introduction}

Rapid emergence of resistant microbes against various drug(s) led the scientists to explore mechanisms of drug resistance in microbes [1]. Pace of lead molecules' discovery necessitates simultaneously newer drug targets to combat with increasing drug resistance in pathogenic bacteria. Methanolic extract of a cyanobacterium, Fischerella sp. was fractionated and the active biomolecule, with broad spectrum antibacterial and antimycobacterial activity was identified as Hapalindole-T (Hap-T) from our lab $[2,3]$. Twenty types of hapalindoles have already been reported from a cyanobacterium Hapalosiphon fontinalis [4]. An artificially synthesised 12-epihapalindole-Q was reported to be antibacterial as well as antimycotic [5]. Such biomolecules may also be modified to develop more potent antimicrobial agents [6]. Proteome analysis, using a combination of 2-DGE and mass-spectrometry drew much attention recently, because of its role in deciphering targets through interaction of genome database as finding cellular target(s) of streptomycin [1], kenamycin and amikacin [7] in Mycobacterium tuberculosis.

The cellular target(s) of Hapalindole-T has not been investigated so far. Tsherefore, non-infectious $E$. coli was used in present work to explore the cellular protein(s) related to E. coli resistance. A comparison of proteome of Hap-T sensitive (Hap- $\mathrm{T}^{\mathrm{S}}$ ) and resistant $\left(\right.$ Hap- $\mathrm{T}^{\mathrm{R}}$ ) strains of $E$. coli would reveal possible target(s) of Hap-T. Identification of such target(s) would facilitate development of an in vitro assay to screen derivatives of Hapalindole-T from drug(s) libraries.

\section{Materials and Methods}

\section{Bacteria, media and Hapalindole-T}

The overnight broth culture of Hap- $\mathrm{T}^{\mathrm{S}}$ strain $\left(\sim 10^{7} \mathrm{cells} / \mathrm{ml}\right)$ was spread on Luria Bertani (LB) agar plate containing 10-50 $\mu \mathrm{g} / \mathrm{ml} \mathrm{Hap}-\mathrm{T}$. Hapalindole resistant colonies $\left(\right.$ Hap- $\left.\mathrm{T}^{\mathrm{R}}\right)$ appeared spontaneously on plates containing $50 \mu \mathrm{g} / \mathrm{ml} \mathrm{Hap-T}$. Escherichia coli was grown at $37^{\circ} \mathrm{C}$ in LB broth and plated on LB agar plates for colony forming units (CFU). Hapalindole- $\mathrm{T}$ (Hap-T, $\mathrm{C}_{21} \mathrm{H}_{23} \mathrm{~N}_{2} \mathrm{ClSO}$, Mr 386, melting point $179-182^{\circ} \mathrm{C}$ ) was isolated from a cyanobacterium Fischerella sp. [2]. The minimum inhibitory concentration (MIC) inhibiting growth of $E$. coli sensitive strain Hap- $\mathrm{T}^{\mathrm{s}}$ was $4.0 \mu \mathrm{g} / \mathrm{ml}$

Isolation of Hap- $\mathrm{T}^{\mathrm{R}}$ strain of $E$. coli and Hapalindole-T sensitivity of Hap- $\mathrm{T}^{\mathrm{S}}$ and Hap- $\mathrm{T}^{\mathrm{R}}$ strains

Bacteria were grown in LB broth. Cells were washed and suspended in PBS to $\sim 10^{7}$ cells $/ \mathrm{ml}$ to which specified concentrations of Hapalindole-T were added. At regular intervals, aliquots of cells were withdrawn, washed with PBS and plated after suitable dilutions on Muller Hinton medium (MH). Plates were incubated at $37^{\circ} \mathrm{C}$ till colonies of visible size appeared.

\section{Two dimensional gel electrophoresis}

Lysates of Hap- $\mathrm{T}^{\mathrm{S}}$ and Hap- $\mathrm{T}^{\mathrm{R}}$ strains were prepared according to the procedure described by O'farrell for 2-DE [8]. Cells of both strains (200 ml each) were centrifuged $(10,000 \mathrm{rpm})$ at $4^{\circ} \mathrm{C}$ and pellet of cells was transferred $0.5 \mathrm{ml}$ lysis buffer $(8 \mathrm{M}$ urea, $2 \mathrm{M}$ thiourea, $0.01 \mathrm{M}$ Tris-HCl, $1 \mathrm{mM}$ EDTA, $1 \% \mathrm{w} / \mathrm{v}$ DTT, $5 \%$ v/v NP-40, 2\% w/v CHAPS, $10 \% \mathrm{v} / \mathrm{v}$ glycerol, $2 \%$ ampholyte $\{0.8 \% \mathrm{pH} 5-7$ and $1.2 \% \mathrm{pH} 3-10\}$, $0.0002 \%$ bromophenol blue and $1 \mathrm{mM}$ PMSF). Cells with lysis buffer were vortexed vigorously and subjected to three rounds of freeze-thaw. After centrifugation the supernatant was separated as cell lysate and stored at $-70^{\circ} \mathrm{C}$. Protein was estimated by Bradford method [9].

$50 \mu \mathrm{g}$ protein was subjected to IEF. This was done in $15 \times 0.3 \mathrm{~cm}$

*Corresponding author: Subhasha Nigam, Amity Institute of Biotechnology, Amity University, Noida 201308, India, Tel: +919868164254; Fax: +91 120 4392295; E-mail: snigam@amity.edu, subhasha.botany@gmail.com

Received July 25, 2016; Accepted February 15, 2017; Published February 17 2017

Citation: Tripathi MK, Kumar M, Deepali S, Asthana RK, Nigam S (2017) Proteomic Analysis of Sensitive and Resistant Isolates of Escherichia coli in Understanding Target(s) of a Cyanobacterial Biomolecule Hapalindole-T. J Aquac Res Development 8: 467. doi: 10.4172/2155-9546.1000467

Copyright: @ 2017 Tripathi MK, et al. This is an open-access article distributed under the terms of the Creative Commons Attribution License, which permits unrestricted use, distribution, and reproduction in any medium, provided the original author and source are credited. 
Citation: Tripathi MK, Kumar M, Deepali S, Asthana RK, Nigam S (2017) Proteomic Analysis of Sensitive and Resistant Isolates of Escherichia coli in Understanding Target(s) of a Cyanobacterial Biomolecule Hapalindole-T. J Aquac Res Development 8: 467. doi: 10.4172/21559546.1000467

Page 2 of 5

vertical glass tubes with $5 \%$ gels containing $6 \%$ ampholyte (four parts pH 3-10 and 2 parts $\mathrm{pH} 5-7)$. The tube gel was given a pre-run for 190 Vh before loading the samples to carry out IEF for 15,000 Vh. The tube gels were removed carefully and kept in SDS-sample buffer $(10 \%$ glycerol, $5 \%$ beta-mercaptoethanol, $2.3 \%$ SDS, $0.0625 \mathrm{M}$ Tris- $\mathrm{HCl}, \mathrm{pH}$ 6.8). It was transferred on to second dimension with resolving (10\%) and stacking (4\%) gels, and run at $150 \mathrm{~V}$ continuously upto the bottom. The gels were stained with coomassie blue R-250 and analysed by Gel Doc (Bio-Rad, USA) using PD quest software. All experiments were performed in three independent replicates and only those spots present in at least two gels each of Hap- $\mathrm{T}^{\mathrm{S}}$ or Hap- $\mathrm{T}^{\mathrm{R}}$ lysates were taken for analysis.

\section{LC-MS analysis of protein spots}

Gel plugs and gel pieces were washed with acetonitrile (ACN, $50-100 \%)$, subjected to speed vacuum for $15 \mathrm{~min}$ and then reduced

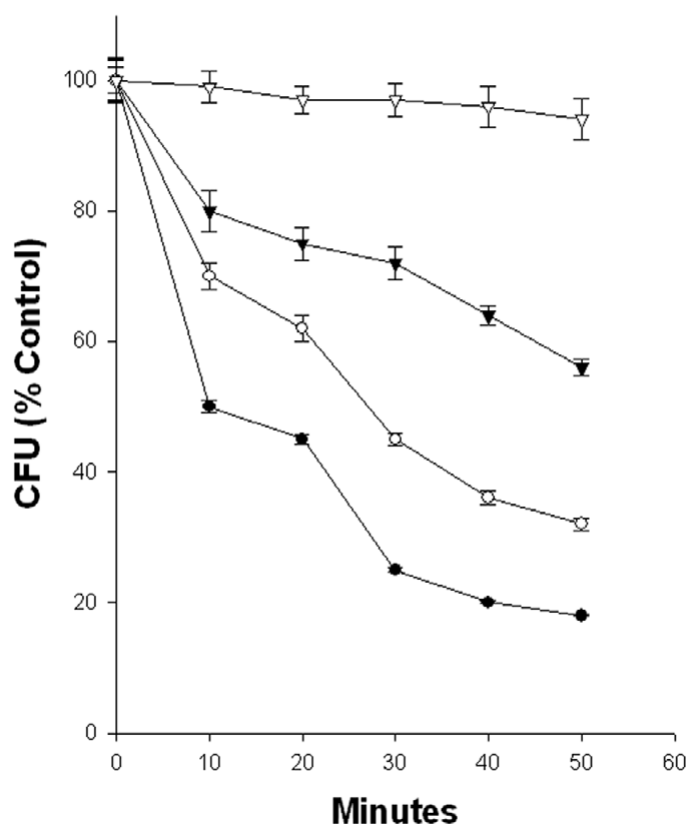

Figure 1: Colony forming ability of $E$. coli (Hap-TR) in $50 \mu \mathrm{g} / \mathrm{ml} \mathrm{Hap}-\mathrm{T}(\nabla-\nabla)$ and Hap- $\mathrm{T}^{s}$ strain after exposure to Hap-T at different time points: $20 \mu \mathrm{g} / \mathrm{ml}$ $(\boldsymbol{\nabla}-\boldsymbol{\nabla}), 25 \mu \mathrm{g} / \mathrm{ml}(\circ-\circ)$ and $30 \mu \mathrm{g} / \mathrm{ml}(\bullet-\bullet)$ by dithiothretol (DTT, $10 \mathrm{mM})$ in ammonium carbonate $(100 \mathrm{mM})$ and $\mathrm{ACN}(5 \%)$ for $1 \mathrm{~h}$ at $55^{\circ} \mathrm{C}$. This was followed by dehydration with $\mathrm{NH}_{4} \mathrm{CO}_{3}(100 \mathrm{mM})$ for $10 \mathrm{~min}$ and $\mathrm{ACN}(100 \%)$ for $20 \mathrm{~min}$. Now alkylation was done in dark by iodoacetamide $(50 \mathrm{mM})$ in $\mathrm{NH}_{4} \mathrm{CO}_{3}$ $(100 \mathrm{mM})$ at room temperature for $30 \mathrm{~min}$. These gel pieces were washed again with $\mathrm{NH}_{4} \mathrm{CO}_{3}(100 \mathrm{mM})$ and $\mathrm{ACN}(100 \%)$ followed by drying in speed vacuum.

Gel pieces were immersed in digestion buffer $\left(50 \mathrm{mM} \mathrm{NH}_{4} \mathrm{CO}_{3}\right.$ trypsin) on ice for $45 \mathrm{~min}$ and kept wet by adding $\mathrm{NH}_{4} \mathrm{CO}_{3}(50 \mathrm{mM})$ and incubated at $37^{\circ} \mathrm{C}$ for $16 \mathrm{~h}$. The supernatants of digested solution were collected. Gel plugs were extracted once with $\mathrm{NH}_{4} \mathrm{CO}_{3}(20 \mathrm{mM})$ for $20 \mathrm{~min}$ followed by two-times extraction with trifluoroacetic acid (TFA, 1\%) in ACN (50\%) followed by ACN (100\%) for 20 min each. All supernatants were pooled and concentrated collectively in speed vacuum. The sample $(16 \mu \mathrm{l})$ was injected into nano LCMS (Agilent 1100 series LC/MSD trap XCT). The data obtained was searched using MASCOT search engine with E. coli-limited search filter. Mass tolerance was kept 50/100 ppm.

\section{Statistical analysis}

All experiments were carried out in triplicates with standard deviation (SD) represented in bars wherever necessary.

\section{Results}

\section{Effect of Hap-T on survival of $E$. coli $\left(\right.$ Hap-T ${ }^{s}$ )}

The colony forming ability of Hap- $\mathrm{T}^{\mathrm{R}}$ and Hap- $\mathrm{T}^{\mathrm{S}}$ are shown in Figure 1 . Hap- $T^{R}$ cells were exposed to $50 \mu \mathrm{g} / \mathrm{ml}$ of Hap- $\mathrm{T}$ to various time intervals (10-60 min.) but the strain was found resistant to Hap-T at $50 \mu \mathrm{g} / \mathrm{ml}$ with more than $90 \%$ survival. Hap- $\mathrm{T}^{\mathrm{S}}$ cells were sensitive to Hap-T, as increasing concentration $(10-60 \mu \mathrm{g} / \mathrm{ml})$ and incubation time, the CFU of such cells decreased.

\section{Analysis of 2-DE gels and identification of protein spots with LC-MS}

Total protein of Hap- $\mathrm{T}^{\mathrm{S}}$ and Hap- $\mathrm{T}^{\mathrm{R}}$ cells by 2-DE, is shown in Figures 2A and 2B. The spots observed in both the gels were comparatively quite comparable and matching. Approximately 200 spots were detected after IEF in $\mathrm{pH}$ range 3-10 with $12 \%$ SDS PAGE. Selected spots showed altered expression of proteins as reflected by their intensities on both the gels. There were thirteen differing protein spots, but only six were numbered. The protein spots 1 and 2 were present in

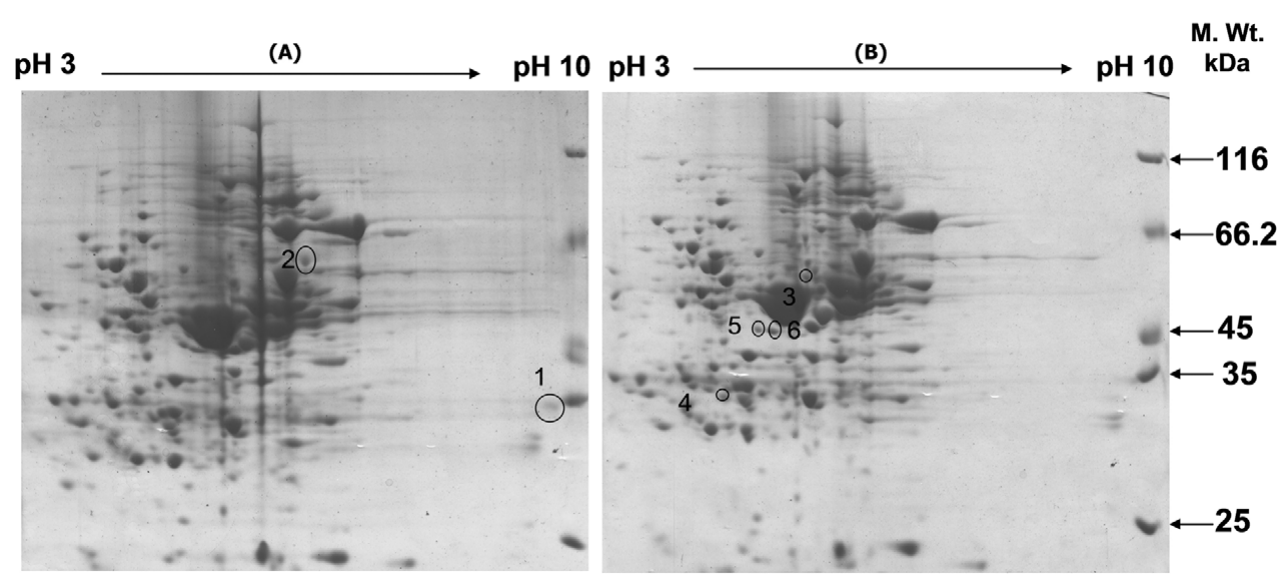

Figure 2: Two dimensional gel ( $\mathrm{pH} 3-10)$ of $E$. coli (A) Hap- $\mathrm{T}^{\mathrm{s}}$ and (B) Hap- $\mathrm{T}^{\mathrm{R}}$ isolates. 
Citation: Tripathi MK, Kumar M, Deepali S, Asthana RK, Nigam S (2017) Proteomic Analysis of Sensitive and Resistant Isolates of Escherichia coli in Understanding Target(s) of a Cyanobacterial Biomolecule Hapalindole-T. J Aquac Res Development 8: 467. doi: 10.4172/21559546.1000467

Page 3 of 5

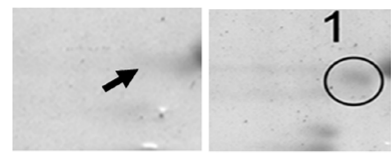

b

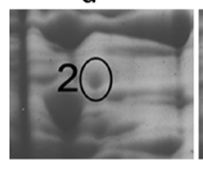

a

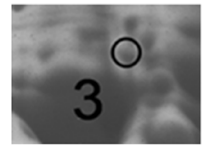

a

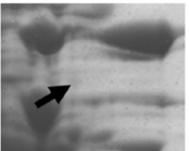

b

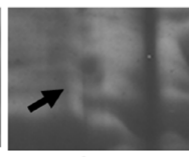

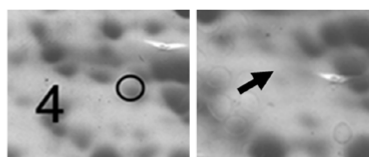

b
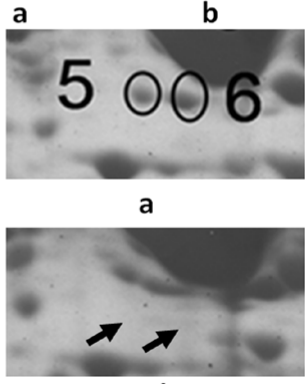

Figure 3: Magnified 2D gels with altered expression of proteins among (a) Hap- $T^{\mathrm{S}}$ and (b) Hap- $\mathrm{T}^{\mathrm{R}}$.

Hap- $\mathrm{T}^{\mathrm{S}}$ only and 3 to 6 were present exclusively in Hap- $\mathrm{T}^{\mathrm{R}}$ (Figure 3). Such spots were digested with trypsin and processed through LC-MS and data showed mixture of proteins as listed in the Table 1.

These proteins were matched with database of E. coli. Among these seventeen proteins three were found unique to Hap- $\mathrm{T}^{\mathrm{S}}$ and identified as outer membrane proteinase (ompP) and antigen 43 (agn43) precursors involved in autoaggregation of $E$. coli cells. Lysyl-tRNA synthetases $(l y s U)$, synthesizes a number of adenyl nucleotides acting as a modulator of heat shock response. The remaining fourteen proteins were found to be associated with Hap- ${ }^{\mathrm{R}}$ strain. Proteins in spot 3 (Figure 3) are known to be involved in amino acid biosynthesis and biodegradation including, aspartate ammonia-lyase (aspA), glycerol kinase complexed $(g l p K)$, dihydrolipoamide dehydrogenase $(l p d A)$, trigonal crystal form of heat shock locus $\mathrm{u}(h s l U)$, glutamine synthetase $(g \ln A)$ and dihydrolipoamide acetyltransferase $(s u c B)$. The spot 4 (Figure 3) contained putative aldolases (yihT), malate dehydrogenases $(m d h)$, and UDP-glucose pyrophosphorylase ( $g a l F)$. These enzymes are associated with glucose metabolism. The spot 5 (Figure 3) was identified as enzyme dTDP-glucose-4, 6-dehydratase $(r f b B)$ and $\mathrm{RmlB}$, an enzyme with multiple participation, especially in nucleotide sugar metabolism as well as biosynthesis of non-ribosomal proteins. The third protein acridine efflux pump $(a c r A B)$ is linked with drug efflux system having broad substrate specificity. The spot 6 (Figure 3 ) possessed $\beta$-keto-acyl-ACP-synthase I $(f a b B)$ and gleceraldehyde3-phosphate dehydrogenase (gapA/GAPDH). FabB catalyzes the elongation of fatty acid from C-10 to unsaturated C-16 and C-18 fatty acids. GAPDH maintains the reducing power of the cells under stress. Thus identification of these proteins suggested that resistance to Hap- $\mathrm{T}$ induced changes associated with cell membrane, amino acid biosynthesis/degradation, carbohydrate metabolism, fatty acid biosynthesis type II including non-ribosomal protein biosynthesizing enzymes.

\section{Discussion}

Natural products from cyanobacteria are likely to offer a new source of antibiotics due to the presence of unique biosynthetic mechanisms $[10,11]$. In this paper we have investigated the cellular targets of an antimicrobial compound Hap-T [2] by comparing total proteome of sensitive and resistant strains of $E$. coli. Since the genome of $E$. coli is sequenced and annotated therefore, it was used as surrogate to find the cellular target(s) of Hap-T. Proteome of the two E. coli strains indicates role of proteins in acquiring resistance against Hap-T. The differentially expressed proteins associated with the Hap- $\mathrm{T}^{\mathrm{S}}$ and Hap- $\mathrm{T}^{\mathrm{R}}$ strains were identified (Table 1). Action of any biomolecule/drug depended on its intracellular accumulation in organism, affecting the metabolism of the cell leading to death $[12,13]$. The colony forming ability of Hap$\mathrm{T}^{\mathrm{S}}$ decreased with the increase in dose of Hap-T and duration of exposure. However, Hap- $\mathrm{T}^{\mathrm{R}}$ strain possessed more than $95 \%$ colony forming ability even in the highest dose of biomolecules $(50 \mu \mathrm{g} / \mathrm{ml})$ and longest duration of exposure (Figure 1). Such differential behaviour in the two strains of $E$. coli might be because of its altered metabolism, reflected in the proteomic analysis (Figure 2). There are reports of marked alterations in total proteome of Mycobacterium tuberculosis and Orientia tsutsugamushi, challenged with drug/biomolecules [14-16]. In fact, antimicrobial drugs are designed after keeping the point in view, that target genes must be essential for the survival of the bacterium. However, such genes are either lack in the host or not affected after exposure of such designed drugs. A comparison of proteome of Hap- $\mathrm{T}^{\mathrm{S}}$ and Hap- $\mathrm{T}^{\mathrm{R}}$ strains provided first global protein profile, clearly indicating altered expression of membrane associated proteins, enzymes related with protein turn over, management of carbon skeleton and energy transduction as well as FabB and aldolases. Such differences in proteins of attenuated and virulent mycobacterial strains helped in designing of novel vaccines [17].

OMPs in bacteria are well known for their role in permeability [18]. Down-regulation of OMPs in Hap- $\mathrm{T}^{\mathrm{R}}$ E. coli strain indicated a mechanism of resistance through restricting permeability of Hap-T inside cell. This observation was in tune with reports of altered protein expression in outer membrane of E. coli resistant to chloramphenicol, ampicillin and tetracycline [19-21]. Likewise, Up-regulation of AcrAB can efflux the Hap-T rendering resistance in the strain. The importance of efflux pump is already established by use of mefloquin as inhibitor in Pseudomonas aeruginosa and E. coli [22]. Sensitivity of the two AcrA mutants of E. coli increased against antibiotics as MICs decreased [23]. Increased $\mathrm{Acr} A \mathrm{~B}$ expression was also corroborated with tigecycline resistance in Enterobacter cloacae [24]. However, importance of membrane targeting drugs has been also reported by Eun et al. [25] as DCAP (a broad spectrum antibiotic) killed slow growing bacteria after targeting membrane. Thus, our observation of membrane targeting by Hap-T gets support with the results. The proteins RfbB and RmlB are synonyms and named as RmlA-D instead of RfbA-D [26] and these proteins were necessary for survival of Mycobacterium as observed by knockout mutants [27]. 
Citation: Tripathi MK, Kumar M, Deepali S, Asthana RK, Nigam S (2017) Proteomic Analysis of Sensitive and Resistant Isolates of Escherichia coli in Understanding Target(s) of a Cyanobacterial Biomolecule Hapalindole-T. J Aquac Res Development 8: 467. doi: 10.4172/21559546.1000467

Page 4 of 5

\begin{tabular}{|c|c|c|c|c|c|c|c|}
\hline Spot & $\begin{array}{l}\text { Matched } \\
\text { Proteins }\end{array}$ & Name of the Proteins & Accession No & MW (kDa) & $\mathbf{P I}$ & Score & $\begin{array}{c}\text { Sequence } \\
\text { Coverage (\%) }\end{array}$ \\
\hline 1 & One & Outer membrane proteinase (omP) & A36944 & 35.47 & 5.9 & 166 & 57 \\
\hline \multirow{2}{*}{2} & \multirow{2}{*}{ Two } & Antigen 43 precursor (agn $43 A)$ & GI 7243712 & 106.89 & 5.5 & 629 & 12 \\
\hline & & Lysyl-tRNA synthetases (LysU) & GI 146689 & 57.35 & 5.1 & 105 & 5 \\
\hline \multirow{6}{*}{3} & \multirow{6}{*}{ Six } & Aspartate ammonia-lyase (aspA) & GI 15804731 & 54.71 & 5.5 & 716 & 30 \\
\hline & & Chain G, Glycerol kinase (glpK) & GI 442946 & 56.34 & 5.3 & 465 & 21 \\
\hline & & Dihydrolipoamide dehydrogenase (IpdA) & GI 15799800 & 50.94 & 5.7 & 440 & 21 \\
\hline & & Chain A, Trigonal Crystal form of heat shock locus U (hslu) & GI 7245635 & 49.54 & 5.2 & 420 & 20 \\
\hline & & Glutamine Synthetase $(g \ln A)$ & GI 146157 & 51.98 & 5.2 & 171 & 11 \\
\hline & & Dihydrolipoamide acetyltransferase $(s u c B)$ & GI 15800431 & 43.98 & 5.5 & 150 & 13 \\
\hline \multirow{3}{*}{4} & \multirow{3}{*}{ Three } & Putative aldolase $(y i h T)$ & GI 15804467 & 32.2 & 5.7 & 181 & 17 \\
\hline & & UDP-glucose pyrophosphorylase (galF) & GI 24266667 & 32.94 & 5.7 & 150 & 17 \\
\hline & & Malate dehydrogenase $(m d h)$ & GI 226907 & 32.41 & 5.6 & 126 & 8 \\
\hline \multirow{3}{*}{5} & \multirow{3}{*}{ Three } & dTDP-glucose 4,6 dehydratase, NAD(P)-binding (rfbB) & GI 16129981 & 40.7 & 5.4 & 644 & 35 \\
\hline & & RmIB & GI 50882468 & 40.68 & 5.2 & 510 & 28 \\
\hline & & Acridine efflux pump (acrAB) & GI 15800192 & 42.22 & 7.6 & 318 & 24 \\
\hline \multirow{2}{*}{6} & \multirow{2}{*}{ Two } & Beta-ketoacyl-ACP synthase I $(f a b B)$ & GI 3805908 & 42.95 & 5.3 & 397 & 30 \\
\hline & & Glyceraldehyde-3-phosphate dehydrogenase(gapA) & GI 26248038 & 36.1 & 6.3 & 247 & 19 \\
\hline
\end{tabular}

Table 1: Protein profile of spots 1, 2 of Hap-Ts and spots 3, 4, 5, 6 of Hap-T ${ }^{\mathrm{R}}$ strains on 2-DE gels, $\mathrm{pH}$ 3-10.

Up-regulation of the enzymes which were involved in the management of the carbon skeleton, amino acid pool as well as energy crisis, seemed to play a key role in the development of Hap-T resistance. Overexpression of LpdA, associated with energy management was known to cause tellurite resistance in E. coli [28] which led the structure based drug design to control parasitic protozoa Trypanosoma cruzi [29]. The enzyme such as HslVU associated with supply of metabolic precursors through proteolytic activity, was used as drug target for Plasmodium falciparum [30]. AspA is little explored as drug target however, 3-nitropropionate acted as a competitive inhibitor to AspA of Bacillus sp. YM55-1 [31]. The presence of GS in human beings as well as in bacteria can be a choice for drug target because of the difference in affinity of ATP binding site in such enzyme [32]. Overexpression of SucB is also known to be associated with persistence in survival and antibiotic resistance in E. coli, through involvement in energy production [33] therefore, mutation in $S u c B$ can serve the purpose. GAPDH reduces the energy crisis of cell under stress via generating more reducing power and influencing the cell survival. However, it is also least understood as a drug target except as a neuroprotective agent [34]. The enzymes, class II aldolases (GalF, MDHs) and fatty acid biosynthetases type II (FAS II) are specific to prokaryotes [35,36]. GalF regulates the cellular level of UDP glucose which is an adaptive mode under stress management [37]. The amino acids of MDHs from E. coli and Salmonella typhimurium and mitochondrial isozyme of eukaryotes have high identity [38] therefore, seemed to be a promising drug target. Increased expression of FabB protein through introduction of multicopy plasmid in E. coli confers thiolactomycin (TLM) resistance [39]. Interaction of TLM and acyl enzyme intermediates of FabB and FabF have shown preferential binding towards each other in $M$. tuberculosis and E. coli [40].

\section{Conclusion}

The strategy of survival in a bacterium is a cascade of mechanisms, operating through a complex metabolic circuit. Over production of individual proteins may be responsible for its survival and resistance against antimicrobials. Such studies on resistant model strain (E. coli) against the target biomolecule in understanding the strategy of survival, justifies our 2-DE approach in the present case.

\section{Acknowledgments}

We are grateful to the Head and Programme Coordinator of Centre of
Advanced Study in Botany, Banaras Hindu University and Direcctor Amity Institute of Biotechnology for laboratory facilities, We are also thankful to TCGA, New Delh for LC-MS of 2-DE protein spots. We are grateful to Dr. B. S. Srivastava, Centra Drug Research Institute, Lucknow, India for critically going through the manuscript.

\section{References}

1. Sharma P, Kumar B, Gupta Y, Singhal N, Katoch VM, et al. (2010) Proteomic analysis of streptomycin resistant and sensitive clinical isolates of Mycobacterium tuberculosis. Proteome Sci 8: 1-11.

2. Asthana RK, Srivastava A, Singh AP, Deepali, Singh SP, et al. (2006) Identification of an antimicrobial entity from the cyanobacterium Fischerella sp. isolated from bark of Azadirachta indica (Neem) tree. J Appl Phyco 18: 33-39.

3. Asthana RK, Deepali S, Tripathi MK, Srivastava A, Singh AP, et al. (2009) Isolation and identification of a new antibacterial entity from the Antarctic cyanobacterium Nostoc CCC 537. J Appl Phycol 21: 81-88.

4. Moore RE, Cheuk C, Yang XQG, Patterson GML (1987) Hapalindoles antibacterial and antimycotic alkaloids from the cyanophyte Hapalosiphon fontinalis. J Org Chem 52: 1036-1043.

5. Kinsman AC, Kerr MA (2010) Total synthesis of ( \pm )-hapalindole Q. Org Lett 3 3189-3191.

6. Feng X, Liu C, Guo J, Song X, Li J, et al. (2012) Recombinant expression, purification, and antimicrobial activity of a novel hybrid antimicrobial peptide LFT33. Appl Microbiol Biotechnol 95: 1191-1198.

7. Sharma D, Kumar B, Lata M, Joshi B, Venkatesh K, et al. (2015) Comparative proteomic analysis of Aminoglycosides Resistant and Susceptible Mycobacterium tuberculosis clinical isolates for exploring potential drug targets. PLoS one 10: e0139414.

8. O'Farrell PH (1975) High resolution two-dimensional electrophoresis of proteins. J Biol Chem 250: 4007-4021.

9. Bradford MM (1976) A rapid and sensitive for the quantitation of microgram quantitites of protein utilizing the principle of protein-dye binding. Anal Biochem 72: $248-254$

10. Mo S, Krunic A, Chlipala G, Orjala J (2009) Antimicrobial ambiguine isonitriles from the cyanobacterium Fischerella ambigua. J Nat Prod 72: 894-899.

11. Dittmann E, Gugger M, Sivonen K, Fewer DP (2015) Natural products biosynthetic diversity and comparative genomics of the cyanobacteria. Trends in Microbiology 23: 642-652.

12. Vijayakumar S, Manogar P, Prabhu S (2016) Potential therapeutic targets and the role of technology in developing novel cannabinoid drugs from cyanobacteria. Biomedicine Pharmacotherapy 83: 362-371.

13. Giuliani A, Pirri G, Bozzi A, Di GA, Aschi M, et al. (2008) Antimicrobial peptides: Natural templates for synthetic membrane-active compounds. Cell Mol Life Sc 65: $2450-2460$ 
Citation: Tripathi MK, Kumar M, Deepali S, Asthana RK, Nigam S (2017) Proteomic Analysis of Sensitive and Resistant Isolates of Escherichia coli in Understanding Target(s) of a Cyanobacterial Biomolecule Hapalindole-T. J Aquac Res Development 8: 467. doi: 10.4172/21559546.1000467

Page 5 of 5

14. Bandow JE, Brotz H, Leichert LI, Labischinski H, Hecker M (2003) Proteomic approach to understanding antibiotic action. Antimicrob Agents Chemother 47: 948-955.

15. Yari S, Hadizadeh TA, Ghanei M, Shokrgozar MA, Fateh A, et al. (2016) Proteomic analysis of drug-resistant Mycobacterium tuberculosis by onedimensional gel electrophoresis and charge chromatography. Archives of Microbilogy 85: 350-258

16. Chao CC, Garland DL, Dasch GA, Ching WM (2009) Comparative proteomic analysis of antibiotic-sensitive and insensitive isolates of Orientia tsutsugamushi. Ann N Y Acad Sci 1166: 27-37.

17. Jungblut PR, Schaible UE, Mollenkopf HJ, Zimny-Arndt U, Raupach B, et al (1999) Comparative proteome analysis of Mycobacterium tuberculosis and Mycobacterium bovis BCG strains: towards functional genomics of microbial pathogens. Mol Microbiol 33: 1103-1117.

18. Lin J, Huang S, Zhang Q (2002) Outer membrane proteins: Key players for bacterial adaptation in host niches. Microbes Infect 4: 325-331.

19. Xu C, Lin X, Ren H, Zhang Y, Wang S, et al. (2006) Analysis of outer membrane proteome of Escherichia coli related to resistance to ampicillin and tetracycline. Proteomics 6: 462-473

20. Li H, Lin X, Wang S, Peng X (2007) Identification and antibody therapeutic targeting of chloramphenicol-resistant outer membrane proteins in Escherichia coli. J Prot Res 6: 3628-3636.

21. Marcellini L, Borro M, Gentile G, Rinaldi AC, Stella L, et al. (2009) Esculentin$1 \mathrm{~b}(1-18)-a$ membrane-active antimicrobial peptide that synergizes with antibiotics and modifies the expression level of a limited number of proteins in Escherichia coli. FEBS J 276: 5647-5664.

22. Vidal-Aroca F, Meng A, Minz T, Page MGP, Dreier J (2009) Use of resazurin to detect mefloquine as an efflux-pump inhibitor in Pseudomonas aeruginosa and Escherichia coli. J Microbiol Methods 79: 232-237.

23. Kwon DH, Lu CD (2007) Polyamine effects on antibiotic susceptibility in bacteria. Antimicrob Agents Chemother 51: 2070-2077.

24. Hornsey M, Ellington MJ, Doumith M, Scott G, Livermore DM, et al. (2010) Emergence of AcrAB-mediated tigecycline resistance in a clinical isolate of Enterobacter cloacae during ciprofloxacin treatment. Int J Antimicrob Agents 35: $478-481$

25. Eun Y, Foss MH, Kiekebusch D, Pauw DA, Westler WM, et al. (2012) DCAP, A broad-spectrum antibiotic that targets the cyatoplasmic membrane of bacteria J Am Chem Soc 134: 11322-11325.

26. Reeves PR, Hobbs M, Valvano MA, Skurnik M, Whitfield C, et al. (1996) Bacterial polysaccharide synthesis and gene nomenclature. Trends Microbiol 4: 495-503.
27. Li W, Xin Y, McNeil MR, Ma Y (2006) rmIB and rmIC genes are essential for growth of mycobacteria. Biochem Biophys Res Commun 342: 170-178.

28. Castro ME, Molina RC, Diaz W, Pradenas GA, Vasquez CC (2009) Expression of Aeromonas caviae ST pyruvate dehydrogenase complex components mediate tellurite resistance in Escherichia coli. Biochem Biophys Res Commun 380: $148-152$

29. Krauth-Siegel RL, Schöneck R (1995) Trypanothione reductase and lipoamide dehydrogenase as target for a structure-based drug design. FASEB J 9: 1138-1146.

30. Subramaniam S, Mohmmed A, Gupta D (2009) Molecular modeling studies of the interaction between Plasmodium falciparum HsIU and HsIV subunits. J Biomol Struct Dyn 26: 473-479.

31. Veetil VP, Raj H, Quax WJ, Janssen DB, Poelarends GJ (2009) Site-directed mutagenesis, kinetic and inhibition studies of aspartate ammonia lyase from Bacillus sp. YM55-1. FEBS J 276: 2994-3007.

32. Nilsson MT, Krajewski WW, Yellagunda S, Prabhumurthy S, Chamarahally GN et al. (2009) Structural basis for the inhibition of Mycobacterium tuberculosis glutamine synthetase by novel ATP-competitive inhibitors. J Mol Biol 393: 504-513.

33. Ma C, Sim S, Shi W, Du L, Xing D, et al. (2009) Energy production genes sucB and ubiF are involved in persister survival and tolerance to multiple antibiotics and stresses in Escherichia coli. FEMS Microbiol Lett 303: 33-40.

34. Medvedev A, Buneeva O, Gnedenko O, Fedchenko V, Medvedeva M, et al. (2006) Isatin interaction with glyceraldehyde-3phosphate dehydrogenase, a putative target of neuroprotective drugs: Partial agonism with deprenyl. $J$ Neural Transm 71: 97-103.

35. Rutter WJ (1964) Evolution of aldolase. Fed Proc, Fed Am Soc Exp Biol 23 : 1248-1257.

36. Zhang YM, White SW, Rock CO (2006) Inhibiting bacterial fatty acid synthesis J Biol Chem 281: 17541-17544.

37. Marolda CL, Valvano MA (1996) The GalF protein of Escherichia coli is not UDP-glucose pyrophosphorylase but interacts with the GalU protein possibly to regulate cellular levels of UDP-glucose. Mol Microbiol 22: 827-840.

38. Goward CR, Nicholls DJ (1994) Malate dehydrogenase, A model for structure evolution, and catalysis. Protein Sci 3: 1883-1888.

39. Tsay JT, Rock CO, Jackowski S (1992) Overproduction of $\beta$-ketoacyl-acy carrier protein synthase I imparts thiolactomycin resistance to Escherichia coli K-12. J Bacteriol 174: 508-513.

40. Machutta CA, Bommineni GR, Luckner SR, Kapilashrami K, Ruzsicska B, et al. (2010) Slow onset inhibition of bacterial beta-ketoacyl-acyl carrier protein synthases by thiolactomycin. J Biol Chem 285: 6161-6169. 